\title{
Saving, Investment and Economic Growth in Cameroun: A Multivariate Approach
}

\author{
Ibrahim Ngouhouo $^{1} \&$ Eric Mouchili ${ }^{2}$ \\ ${ }^{1}$ Programming and Monitoring of Academic Affairs, Faculty of Economics and Management, University of \\ Dschang, Cameroon \\ ${ }^{2}$ Faculty of Economics and Management, University of Dschang, Cameroon \\ Correspondence: Ibrahim Ngouhouo, Programming and Monitoring of Academic Affairs, Faculty of Economics \\ and Management, University of Dschang, Cameroon. E-mail: ngouhouo@yahoo.fr
}

Received: June 9, 2014

doi:10.5539/ijef.v6n9p244
Accepted: July 1, 2014

Online Published: August 25, 2014

URL: http://dx.doi.org/10.5539/ijef.v6n9p244

\begin{abstract}
The nature of the link between savings investment and growth in empirical and theoretical research in Cameroon is not well known in Cameroon. The objective of this study is to examine the nature of the relationship between savings, investment and economic growth in Cameroon from 1980 to 2010. In order to achieve our objective, data from World Bank were collected and tested in a Vector Auto Regressive Model. The Toda-Yamamoto (1995) Granger non causality test used in testing the hypothesis which was to investigate the nature of the link between investment, saving and growth showed the following results: In Cameroon, there is a unidirectional causal relationship from investment to savings, from growth to savings, and finally from growth to investment. Meanwhile, there is no causal link from savings to investment, savings towards growth and investment to growth in Cameroon. Thus, the recommendation among other things is that, Cameroon government should create an incentive framework conducive to the enhancement of gross national savings and investment to strengthen production and economic growth.
\end{abstract}

Keywords: savings, investment, growth, causality test

\section{Introduction}

In the aftermath of independence, Cameroon opted for a development strategy based on five-year plans with main objective to revive a general investment and economic growth. Indeed, until the second half of the 1980s, Cameroon's economic growth remained positive and relatively stable in term of economic growth, with acceptable rates of investment and saving. This period of prosperity was supported by oil revenues earned and especially export revenues from agricultural products. Between 1986 and 1994, Cameroon experienced a global economic crisis with a negative economic growth. Production dropped significantly due to low investment and insignificant savings stock to boost the economy. Multiple liquidations of public enterprises and the closure of some commercial banks followed and poverty remained the norms of the day. Conscious of this growing state of poverty, the Cameroon government accepted the Structural Adjustment Programme (SAP) at the beginning of the 90s, which had major macroeconomic objectives: to advocate economic liberalization and especially to reduce the level of state intervention in the economy in terms of investment. This initiative brought its fruits as up to 1995; economic growth became positive through higher domestic investment with the share of high private investment as a result of multiple privatizations. Many other measures were put in place like the three-year plan in 1997, the decision point, the completion point, the very achievement of the latter and the salary adjustments which had in one way or another had positive influence on investment, savings and economic growth. Despite the move towards an integrated global economy, Cameroon remained marginalized because of the weaknesses of its savings and investments which are major determinants of economic growth. Thus, what could be the link between savings, investment and economic growth in Cameroon? Before answering this question, and having a looking at the methodology and results of this research, it is first of all necessary to analyze the evolution of investment, savings and economic growth in Cameroon and then review some works in this area of study before.

\section{Evolution of Savings, Investment and Economic Growth in Cameroon}

In order to have the above evolution clearly we review the period before the crisis, the period of structural 
adjustment and that under the initiative for Heavily Indebted Poor Countries (HIPC) to the present.

Cameroon has experienced two decades of sustained economic growth since independence in 1960. The agricultural sector then was boosted by the implementation of five-year plans, especially the production of cash crops for export. Cameroon witnessed a growth rate of 15\% GDP in nominal terms and by more than $7 \%$ in real terms in 1980 (CAFRAD, 2000). At the same time, the investment rate increased from $16 \%$ in 1970 to $31 \%$ in 1978. This could have been explained by the large investments for oil and at the same time the necessary investments for the implementation of five-year plans. Meanwhile, the savings rate followed a growing trend of the economy to attain a rate of close to $30 \%$ in 1982 . It should be noted that these dates correspond to periods of great oil exploitation, and also because Cameroon was not touched by the crisis as it was the case with most developing countries. From the fore-going, we can graphically present the evolution of savings, investment and economic growth for the period 1980 to 1985 in Cameroon.

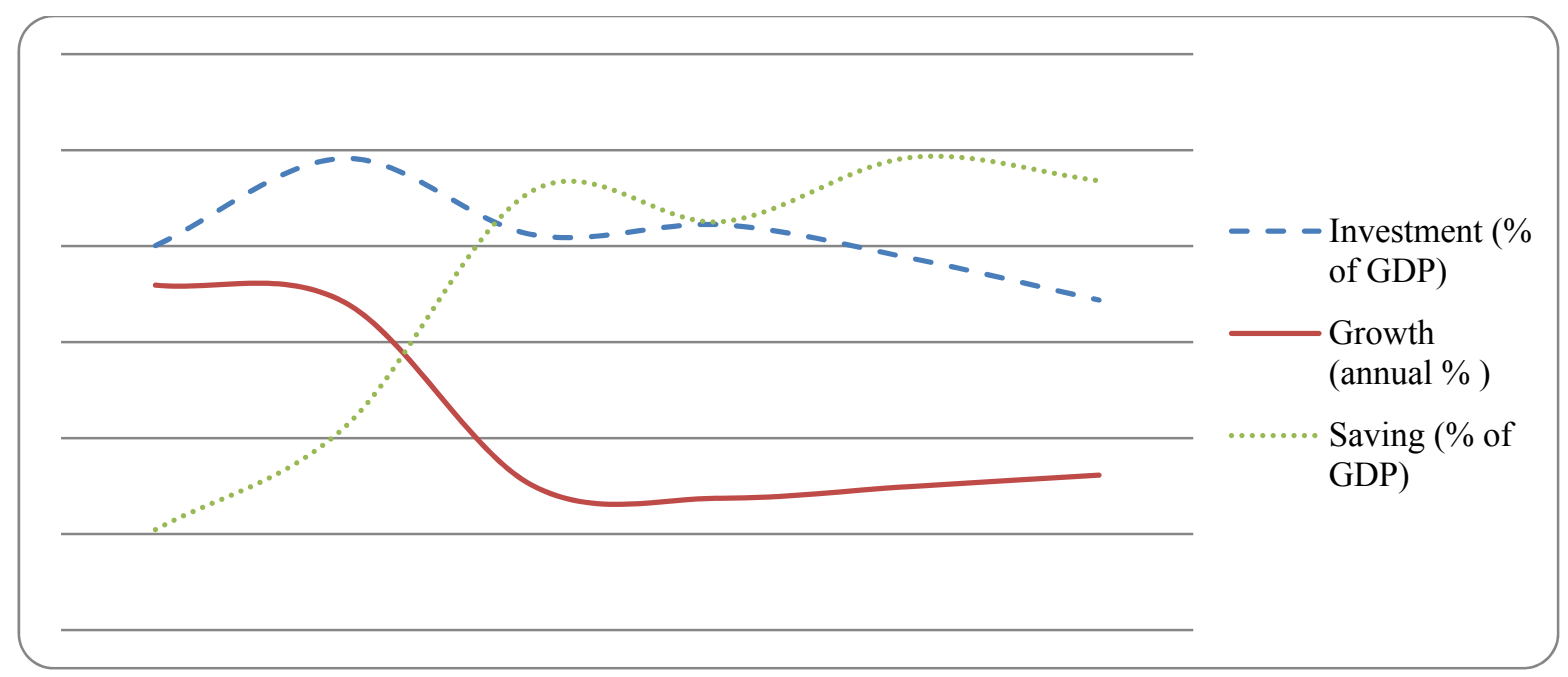

Figure 1. Evolution of savings, investment and growth in Cameroon before the crisis (1980-1985)

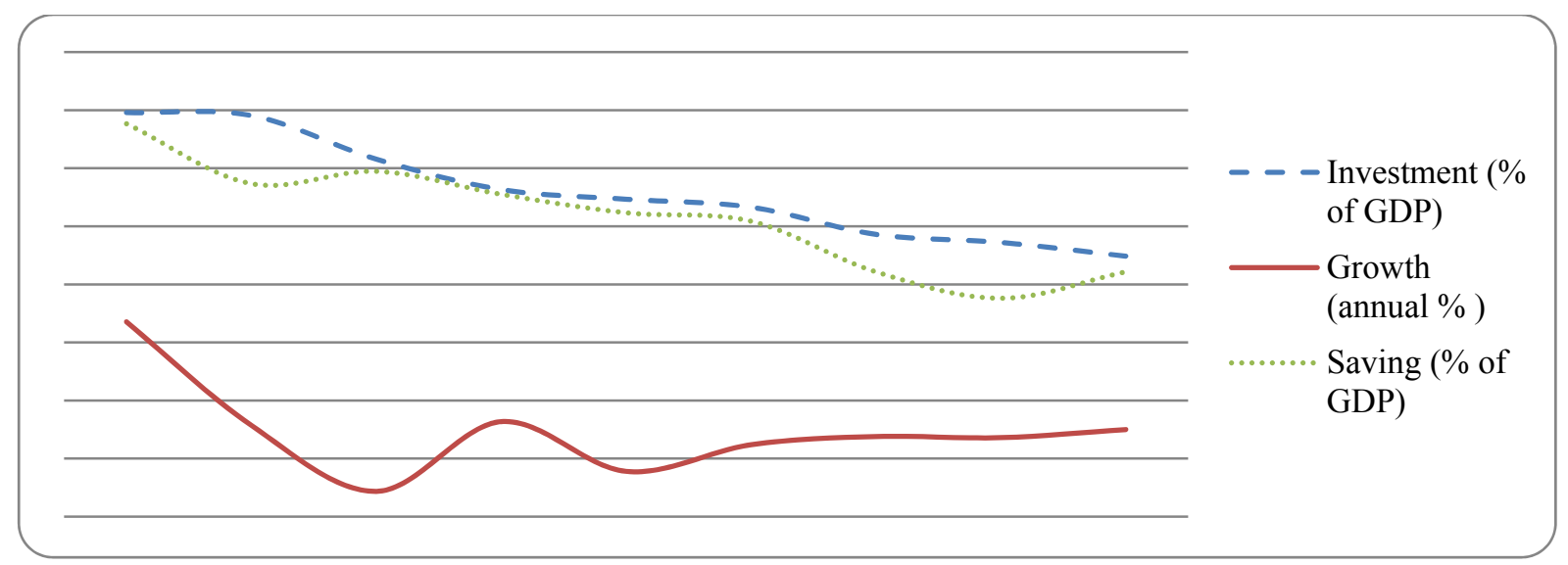

Figure 1. Evolution of saving, investment and growth under the SAP (1986-1994)

Source: The World Bank Indicators, 2010.

The oil shocks of 1973 and 1981 marked the starting point of the excessive indebtedness for a developing country like Cameroon. This crisis resulted in the increase in oil prices and this had a negative impact on the functioning of the economy. Cameroon resorted to indebtedness in order to increase investment opportunities and to redress the balance of payments. However, the difficulty of ensuring Cameroon's debt servicing was at the origin of the (SAP) initiated by the IMF and the World Bank. Thus, the implementation of Structural Adjustment policies was the government's response to the worsening economic crisis experienced in the early $80 \mathrm{~s}$. From 
1987, Cameroon entered the negative phase of growth. This clearly showed the stalemate of the situation, which was accompanied by a significant decrease in several macroeconomic indicators such as savings, investment and growth as seen in Figure 2 below.

Cameroon was accepted in the HIPC initiative in 1997, when the IMF and World Bank launched a relief program of crippling debt burden of the poorest countries in the world. In August 1997, the Cameroon Government signed for the first time an agreement with the International Monetary Fund after completing satisfactorily the program of reference conducted by the IMF staff called "the Enhanced Structural Adjustment Facility (ESAF)". The IMF gave its support to economic and financial programs in the medium term that the Cameroonian authorities had put in place to stop the fall in investment (PRSP, 2003). From 1997 to 2000, real GDP grew at $4.5 \%$ on average (PRSP, 2003); the situation of public finances improved through better mobilization of its own revenues and voluntary rationalization of spending. Once the decision point was achieved on October 2000, Cameroon received 256 billion CFA francs (Wouofo C., 2006).

\section{Literature Review}

\subsection{Theoretical Literature}

Several theoretical studies have focused on the analysis and explanation of the closed relationship between economic growth, investment and savings. If investment is recognized by all as the engine of economic growth, the role of savings is subject to theoretical debates between different schools of economic thought.

For classical macroeconomists, output growth depends first and foremost on investment, which in turn depends on the savings rate. In this case, the interaction between demand and supply of loanable funds determines the level of investment. Thus, for the classical economists, savings can finance additional investments. The fit between savings and investment is explained by the combined effects of the of market law of Say (1803) and by the role of interest rate. According to Turgot (1766), and as well as Smith (1776), savings are considered automatically to be used in financing investment. Hayek (1931) on his part showed how an economy can achieve a capital intensive structure of production. Savings are important for the evolution of per capita variables according to Solow (1956) growth model, Cass (1965), and Koopmans (1965). This role was also experienced in the endogenous growth models of AK, including Frankel (1962) and Romer (1986). For these authors, a high saving rate can drive economic growth. In their argument, savings can produce additional investments and therefore more income. This would require that the law of markets is verified, that is, any additional production is effectively transformed into income. In this sense, savings is a stimulant for growth and investment.

In summary, all neoclassical models concluded on the prime role of savings for sustained growth.

On the other hand, Keynesians and neo-keynesians believed that savings remained a source of instability contrarily to neoclassical models which assign a passive role to savings. According to these models, the main lever that moves the economy onto the path of economic growth is investment, which is induced by the «animal spirits of entrepreneurs." Savings is rather a drag on growth because it creates a demand deficit. Investment therefore must be preferred so as to reduce the deficit and to induce growth and savings. Malthus, Marx and Keynes questioned the prime role to investment. They consider in this case that, savings reduce consumption demand and therefore production. For Keynes (1936), since saving reduces consumption, it prevents the demand to be at the expected level. Harrod (1948) and Domar (1947) developed a model to explain the instability of balanced growth. In the model, investment has a dual effect:

First, on demand through a multiplier effect, a positive net investment demand therefore is increasing aggregate demand as indicated by the multiplier formula.

$$
\Delta \boldsymbol{Q}_{\boldsymbol{d}}=\frac{\Delta \boldsymbol{I}}{\mathrm{s}}
$$

Second, on production through an accelerator effect, thus investment is an additional capacity which performs the following additional production:

$$
\Delta Q_{P}=\rho I=\frac{I}{v}
$$

Where $Q_{d}$ and $Q_{P}$ are respectively the potential demand and production, $\mathbf{s}$ being the saving rate and $\boldsymbol{v}=\frac{\boldsymbol{K}}{\boldsymbol{Q}}$, the coefficient of capital.

Therefore, the equilibrium is $Q_{d}=Q_{P}$ or $\frac{\Delta \boldsymbol{I}}{\boldsymbol{I}}=\frac{\boldsymbol{s}}{\boldsymbol{v}}$.

In this case investment must grow at a constant rate to ensure equilibrium in the market for goods and services. Harrod and Domar (1948) were pessimistic about the stability of such a system because the growth rate of full 
employment (or natural growth rate) could differ from the growth rate of equilibrium and throw the economy into a sustainable state of sub- utilization of capital (overfunding that discourages investment activities) or in a state of persistent unemployment.

After presenting the theoretical controversies between savings and investment, an empirical development on the linkage can be examined.

\subsection{Empirical Literature}

The empirical literature has focused on the causality between savings and growth, savings and investment and finally between investment and growth.

With respect to the relationship between savings and economic growth, Feldstein and Horioka (1980) interpreted the positive causality between savings and investment as a result of imperfect international capital mobility. Under these conditions, savings become a limiting factor for investment. Carroll and Weil (1994), studying the relationship between savings and growth (in both macro and micro levels showed that income growth rate is above that of savings. Equally, Blomstrom, Lipsey and Zejan (1992) led to the conclusion that the increase in GDP leads to an increase in fixed capital formation which is stronger than the impact on growth. Bjorn Anderson studied the causality between saving and growth with data from Switzerland, United Kingdom and United States; using both the long and short run dynamics and country heterogeneity using the VAR methodology: His study led to the conclusion that the causal link between savings and output differs depending on the country and that causality runs more easily in both directions (from savings to growth and vice versa) when the study is conducted taking into account the long-term adjustments.

Also, as regards to the relationship between savings and investment, theories of endogenous growth since the mid- 1980s, mainly those of Lucas (1988), Romer (1990) and Barro (1990) confirm the idea that accumulation of physical capital is the key driver of economic growth in the long term. Bacha (1990), Jacppelli and Pagano (1994) also argued that savings contributed to the increase in investment and GDP growth in the short term. Palley (1996) used a VAR model to examine the relationship between savings and investment in the American case; the main conclusion was that, investment caused saving. He argues that investment spending leads to increase in both the private and public savings. In addition, the increase in private savings actually has no effect on investment spending. He suggested that policies to increase private and public savings are not likely to increase investment and can lead to inflationary pressures. Ebeke (2006) examined the causal relationship between savings and investment in the CEMAC zone taking into account the level of financial development. He discovered that there was heterogeneity in the causality between savings and investment in the area and that it could be due to the heterogeneity of the level of financial development. He concludes that when the level of financial development is high, saving causes investment (Cameroon, Congo and Gabon). In the short and long term, when the level of financial development is low, investment causes savings (Chad and Central African Republic).

Finally, concerning the relationship between investment and economic growth, many international comparative studies have found a strong contemporary relationship between investment and growth (Barro, 1991; Levine \& Renelt, 1992). An increasing number of studies point out that, causality runs from growth to investment, rather than the opposite. Studies in some countries concluded that investment does not play any important role in economic growth (Blomstrom \& Zejan, 1993) in a brief overview. In recent articles on a range of countries, Carroll and Weil (1993) and Blomstrom, Lipsey and Zejan (1993) provided convincing evidence of the validity of the assumption that growth has a causal effect on investment. In his analysis of common stochastic trends in a set of 13 U.S. macroeconomic cointegrated variables from 1959 to 1992, Yoon (1993) confirmed that in the long-term growth causes investment. For developing countries (DCs), the results showed that investment and growth are jointly determined, that is, each variable has a causal impact on the other. For developing countries, there has been a decrease in the goodness of fit when the investment is added to the constrained growth model and a slight increase when growth is added to the constraint model of investment. In total, the analysis seems to give slightly more weight to the hypothesis that growth causes investment rather than the opposite. But the weight is very low.

In light of this literature review, we find two main limitations in the Cameroonian context: The first is related to the monetary nature of the interest rates in the Keynesian sense that advocates the marginal efficiency of capital or capital gain expected by that invested since in Cameroon as in all developing countries investment or savings is not necessarily an inverse function of interest rates. This to the extent that when interest rates drop, one do not necessarily invest or when interest rates increase one do not necessarily save because everything is played at the expected capital gain by investing. 
The second limitation is that in the context of Cameroon as well as in that of the developing countries, the Harrod Domar theory requires the presence of a lot of capital to invest in balanced growth. Yet in reality, these countries lack capital and generally make use of Official Development Assistance (EPA) and HIPC funds.

\section{Methodology}

The methodology of this study begins with an analysis of the nature and sources of data.It then goes on to specifying the econometric model which is used to estimate and analyze the hypothesis after a preliminary test of unit root. Finally, this section ends up by considering the estimation techniques used.

\subsection{Nature and Source of Data}

The data used in this study are from secondary sources and come most especially from the annual publication of the World Bank "World Development Indicators Book" and "Africa Development Indicators Books" contained in a CD- ROM from the World Bank Institute (WBI, 2010). The data is supplemented by the various reports of the Ministry of Economy and Regional Planning, and the National Directorate of Statistics of Cameroon (Cameroon in figure). Estimates are made to complete the missing data for some variables. The study has made use of longitudinal information on variables in the 1980-2010 periods. Word and Excel are used in processing while the data is analyzed by the use of E-views.

\subsection{Model Specification}

The econometric model is a Vector Autoregressive (VAR) model that is particularly effective in the study of simultaneity between macroeconomic variables. It has several advantages such as, its simplicity, the possibility of estimating a system of small sizes, simulation of structural shocks and it has a limited number of constraints and economic assumptions. It is also effective in empirical tests and forecasting.

$$
\begin{aligned}
& E N B_{t}=\alpha_{0}+\alpha_{1} E N B_{t-i}+\alpha_{2} C R O_{t}+\alpha_{3} I N V_{t}+\alpha_{4} T I R_{t}+\alpha_{5} T C H_{t}+\alpha_{6} I N F_{t}+\varepsilon_{1 t} \\
& I N V_{t}=\beta_{0}+\beta_{1} I N V_{t-i}+\beta_{2} E N B_{t}+\beta_{3} C R O_{t}+\beta_{4} T I R_{t}+\beta_{5} T C H_{t}+\beta_{6} I N F_{t}+\varepsilon_{2 t} \\
& C R O_{t}=\gamma_{0}+\gamma_{1} C R O_{t-i}+\gamma_{2} E N B_{t}+\gamma_{3} I N V_{t}+\gamma_{4} T I R_{t}+\gamma_{5} T C H_{t}+\gamma_{6} I N F_{t}+\varepsilon_{3 t}
\end{aligned}
$$

$\mathbf{t}$ is the period and $\mathbf{t}-\mathbf{i}$ represents past periods with $\mathrm{i}$ being the number of lags, determined by minimizing the selection criterion. i goes from January to March.

$\mathrm{ENB}_{\mathrm{t}}$ is the saving in period $\mathrm{t}$;

$\mathrm{CRO}_{\mathrm{t}}$ is the annual growth rate in year $\mathrm{t}$;

$\mathrm{INV}_{\mathrm{t}}$ is the investment in year $\mathrm{t}$;

$\mathrm{TIR}_{\mathrm{t}}$ is the real interest in period $\mathrm{t}$;

$\mathrm{TCH}_{\mathrm{t}}$ is the exchange rate in year $\mathrm{t}$;

$\mathrm{INF}_{\mathrm{t}}$ is the inflation rate in year $\mathrm{t}$;

$\alpha_{0}, \beta_{0}$ et $\gamma_{0}$ are constant parameters.

$\varepsilon_{1 t}, \varepsilon_{1 t}$ et $\varepsilon_{3 t}$ Are error terms; and

$\alpha, \beta$ et $\gamma(1 \ldots 6)$ are coefficients of variables.

\subsection{Unit Root Test}

The stationarity or otherwise the non-stationarity of a serie can strongly influence its behaviour and propertiese.g., persistence of shocks will be infinite for non stationary series. If two variables are trending over time, a regression of one on the other could have a high R2 even if the two are totally unrelated leading to spurious regressions. If the variables in the regression model are not stationary, then it can be proved that the standard assumptions for asymptotic analysis will not be valid. In other words, the usual "t-ratios" will not follow a t-distribution, so one cannot validly undertake hypothesis tests about the regression parameters.

\subsection{Techniques of Estimation}

In order to estimate the VAR model, it is necessary to first of all look at the lag length of the different variables of the model. The criteria used in selecting the lags are: The Akaike information criteria (CIA), Schwarz criteria (CS), Hannan -Quinn (HQ); the final prediction criterion (FPC), LR. The one that present the minimum lag is preferred to others (see table 2). In the case of species, if the minimum lag is $p$, the number of lags to be used according to the method of Toda -Yamamoto will be equal to $(p+1)$, ie the minimum criterion increased by one. 


\subsection{Granger Causality Test of Toda-Yamamoto}

The implementation of causal relationships between economic variables allows for a better understanding of economic phenomena, and provides additional information about the priority of events between them. Among the various procedures that exist, the Toda - Yamamoto (1995), however, is simpler and gives better results. This test is chosen for its simplicity and the fact that it responds well to the data. Furthermore, there is no need to test for the stationarity of the variables. All what is required is to increase the normal lag selected by unity and estimate the model at level.

\section{Results}

Table 1. Unit root test results

\begin{tabular}{llll}
\hline Variables & Test & Probability & Decision. \\
\hline CRO & ADF & O, 0008a & stationary \\
ENB & ADF & O, 0177b & stationary \\
INV & ADF & 0,6919 & Non Stationary \\
TCH & ADF & $0,0035 \mathrm{a}$ & Stationnary \\
TIR & ADF & $0,0001^{\mathrm{a}}$ & Stationary \\
TINF & ADF & $0,0003 \mathrm{a}$ & Stationary \\
\hline
\end{tabular}

Source: Eviews 5.2. Stationary variables: $\mathrm{a}=1 \% \mathrm{~b}=5 \%$.

The variables (ENB, TCH, and TIR TINF) are integrated of order 0 , that is I $(0)$ and therefore stationary except the investment (INV) which is integrated of order one, that is I(1) and therefore non-stationary. An analysis of co-integration can be carried out but the method of Toda-Yamamoto ignores this test and recommends a direct estimation of the model. After the unit root test, the number of lags is selected from table 2. In view of the table, all the criteria present the same number of lag, that is $\mathrm{P}=2$ and the required lag for the Toda-Yamamoto method is $\mathrm{K}=\mathrm{P}+1$ which is 3 .

Table 2. Selection of lag length criteria

\begin{tabular}{lllllll}
\hline Lag & LogL & LR & FPC & AIC & SC & HQ \\
\hline $\mathbf{0}$ & -7.917321 & NA & 0.000740 & 1.301332 & 1.736827 & 1.426739 \\
$\mathbf{1}$ & 29.23891 & 57.16343 & $8.67 \mathrm{e}-05$ & -0.864532 & 0.006458 & -0.613718 \\
$\mathbf{2}$ & 44.19621 & $19.55955^{*}$ & $5.85 \mathrm{e}-05^{*}$ & -1.322786 & $-0.016301^{*}$ & $-0.946565^{*}$ \\
$\mathbf{3}$ & 48.87731 & 5.041178 & $9.35 \mathrm{e}-05$ & -0.990562 & 0.751418 & -0.488935 \\
$\mathbf{4}$ & 63.08448 & 12.02145 & $8.11 \mathrm{e}-05$ & $-1.391114^{*}$ & 0.786361 & -0.764080 \\
$\mathbf{5}$ & 71.47601 & 5.164022 & 0.000137 & -1.344309 & 1.268661 & -0.591868 \\
\hline
\end{tabular}

Source: e-views 5 .

In view of the table, all the criteria present the same number of lag, that is $\mathrm{P}=2$ and the required lag for Toda-Yamamoto is $\mathrm{K}=\mathrm{P}+1$ which is 3 .

\subsection{Results of VAR model}

Table 3. Estimation of the VAR model

\begin{tabular}{llll}
\hline & CRO & LOGENB & LOGINV \\
\hline & 0.317351 & -0.00148 & 0.004137 \\
$\mathrm{CRO}(-1)$ & $(0.21528)$ & $(0.00384)$ & $(0.00315)$ \\
& {$[1.47415]$} & {$[-0.38569]$} & {$[1.31273]$} \\
& 0.001507 & 0.010075 & 0.005023 \\
$\mathrm{CRO}(-2)$ & $(0.24009)$ & $(0.00428)$ & $(0.00351)$ \\
& {$[0.00628]$} & {$[2.35439]$} & {$[1.42911]$} \\
$\mathrm{CRO}(-3)$ & 0.108458 & 0.009234 & -0.004808 \\
& $(0.26262)$ & $(0.00468)$ & $(0.00384)$ \\
\hline
\end{tabular}




\begin{tabular}{|c|c|c|c|}
\hline & [ 0.41298$]$ & {$[1.97277]$} & {$[-1.25076]$} \\
\hline & 18.48358 & 0.526463 & 0.200815 \\
\hline \multirow[t]{3}{*}{ LOGENB(-1) } & (11.3087) & $(0.20156)$ & $(0.16554)$ \\
\hline & [ 1.63446$]$ & [2.61190] & [1.21306] \\
\hline & -8.17866 & 0.094452 & 0.026654 \\
\hline \multirow[t]{3}{*}{ LOGENB(-2) } & $(10.9826)$ & $(0.19575)$ & $(0.16077)$ \\
\hline & {$[-0.74469]$} & {$[0.48251]$} & [0.16579] \\
\hline & 3.051011 & -0.023057 & 0.047255 \\
\hline \multirow[t]{3}{*}{ LOGENB(-3) } & $(6.75086)$ & $(0.12033)$ & $(0.09882)$ \\
\hline & [ 0.45194$]$ & {$[-0.19162]$} & {$[0.47817]$} \\
\hline & -6.455575 & -0.784036 & 0.479176 \\
\hline \multirow[t]{3}{*}{ LOGINV(-1) } & $(17.2142)$ & $(0.30682)$ & $(0.25199)$ \\
\hline & {$[-0.37501]$} & {$[-2.55535]$} & [1.90154] \\
\hline & -16.40915 & 0.377624 & 0.052155 \\
\hline \multirow[t]{3}{*}{ LOGINV(-2) } & $(17.6051)$ & $(0.31379)$ & $(0.25772)$ \\
\hline & {$[-0.93207]$} & {$[1.20343]$} & {$[0.20237]$} \\
\hline & 1.707945 & 0.167490 & 0.090209 \\
\hline \multirow[t]{3}{*}{ LOGINV(-3) } & $(13.6559)$ & $(0.24340)$ & $(0.19990)$ \\
\hline & {$[0.12507]$} & [0.68813] & {$[0.45126]$} \\
\hline & 8.654208 & 0.786783 & 0.084678 \\
\hline \multirow[t]{3}{*}{$\mathrm{C}$} & $(23.7516)$ & $(0.42334)$ & $(0.34769)$ \\
\hline & {$[0.36436]$} & [1.85850] & {$[0.24354]$} \\
\hline & -0.266716 & 0.001325 & 0.002127 \\
\hline \multirow[t]{3}{*}{ TIR } & $(0.13371)$ & $(0.00238)$ & $(0.00196)$ \\
\hline & [-1.99473] & {$[0.55585]$} & [1.08643] \\
\hline & -0.18992 & 0.001626 & 0.000297 \\
\hline \multirow[t]{3}{*}{ TINF } & $(0.10353)$ & $(0.00185)$ & $(0.00152)$ \\
\hline & {$[-1.83439]$} & [0.88096] & [0.19589] \\
\hline & 0.011557 & $-5.93 \mathrm{E}-05$ & $4.21^{\mathrm{E}}-05$ \\
\hline \multirow[t]{2}{*}{$\mathrm{TCH}$} & $(0.00813)$ & $(0.00014)$ & $(0.00012)$ \\
\hline & [1.42092] & {$[-0.40901]$} & [0.35392] \\
\hline $\mathrm{R}^{2}$ & 0.701917 & 0.882762 & 0.839490 \\
\hline $\mathrm{R}^{2}$ Ajusté & 0.463450 & 0.788971 & 0.711083 \\
\hline F-statistic & 2.943456 & 9.412034 & 6.537693 \\
\hline
\end{tabular}

Source: Auteur à partir des résultats présentés à l'annexe.

- In ( ) are the standards deviation.

- In [ ] are the values of Student-t.

- C is the constant.

The coefficient of determination (R2) is $70 \%$ for the growth equation in the VAR system, $88 \%$ for the saving equation and $83 \%$ for the investment equation, showing globally that there is a good fit with an overall adjusted R2 of more that $65 \%$.

The main objective was to test the nature of causal relationship between the saving, investment and the growth variable. First, we examine the causal relationship between the saving and investment, then between the saving and growth and finally between the growth and investment.

The relationship between saving and investment shows that there is a unidirectional causality between these two variables in Cameroon, from investment to savings. In reality, the causality from investment to savings noted in Cameroon could be explained by the impact of the Structural Adjustment Program and the HIPC initiative which put the country into a vast construction site in all sectors, creating multiple jobs and increasing income. We may believe that the profit from investment is spared to consolidate the existing stock of savings.

As regards the causal link between savings and economic growth, the results show that there is a unidirectional causality between the two variables, from economic growth to saving. The explanation could be that the business environment is improving in this country, the return to growth and to a surplus for savings. When growth is strong enough, it may be good saving; we have the example of 1995 where the positive growth rate resulted in an 
increase in the savings rate. This is explained by the fact that large companies installed are subsidiaries of multinational corporations that use their added value to save a good deal depending on the deposit interest rate and the other part is devoted to either consumption or reinvestment.

All economic theories have demonstrated the direct link between investment and economic growth. The Cameroon case is not an exception and the review of charts shows that there is a unidirectional Granger causality from economic growth to investment, without opposite effect. Indeed, the establishment of the SAP has been successful since the liberalization of the economy; many privatizations have made competitive enterprises to create wealth, the devaluation of the CFA rendered the national economy productive, contributed to the raising growth rate since 1995. The debt cancellation under the completion of the HIPC initiatives has had positive financial effects. This concern in particular Cameroon, which has reached the completion point. It has reduced the amount of public debt which leading to growth. The infrastructure put in place has encouraged investors to come to Cameroon thanks to the favorable business environment, even though the country's credibility has remained under the control of the World Bank, IMF and other foreign donors.

Finally, there is a uni-directional causality from economic growth to investment, again from economic growth to savings and finally from investment to savings. Schematically, this can be illustrated as in figure 2 below.

\section{Conclusion}

The main objective of the study was to examine the nature of the relationship between savings, investment and economic growth in Cameroon. Using a quantitative study, assumptions and defined objectives were partially met for most variables. Economic growth has a causal link to the savings and investment without reverse effect, which confirms our research hypothesis and some recent works in other countries such as Carroll and Weil (1994) and Elbadawi and Mwega (2000). Investment involves savings without the reverse effect, which confirms the assumptions and the literature reviews like the works of Palley (1996).

Other analyzes could quantify the magnitude of capital flight and crowd out effect of investment and economic growth in Cameroon.

\section{References}

Barro, R. J. (1991). Economic growth in a cross section of countries. Quarterly Journal of Economics, 106, 407430. http://dx.doi.org/10.2307/2937943

Blomström, M., Lipsey, R. E., \& Zejan, M. (1992). What explains developing country growth? NBER Working Paper No. 34.

CAFRAD. (2000). Séminaire sur les activités de formation en éthique professionnelle pour les fonctionnaires d'aujourd'hui. Projet de CD-Rom pour l'Afrique, Tanger- Maroc, Mai-juin.

Cass, D. (1965). Optimum Growth in an Aggregate Model of Capital Accumulation. Review of Economic Studies, 32, 233-240. http://dx.doi.org/10.2307/2295827

CNUCED. (2002). World Development Report: Transnational Corporation and Export Competitiveness. New York and Geneva, United Nations.

De, L., \& Summers, L. (1993). How Strongly Do Developing Countries Benefit from Equipment Investment. Journal of Monetary Economics, 32, 395-416. http://dx.doi.org/10.1016/0304-3932(93)90024-A

Dickey, D. A., \& Fuller, W. A. (1981). Likelihood Ratio Statistics for Autoregressive Time Series with a Unit Root. Econometrica, 49(4), 1057-1072. http://dx.doi.org/10.2307/1912517

Ebeke, C. (2006). Hétérogénéité financière et interaction entre épargne et investissement en zone CEMAC. Mémoire DEA Economie PTCI, Université de Yaoundé-II SOA, Cameroun.

Elbadawi, I. A., \& Mwega, F. M. (1998). Can Africa's Saving Collapse Be Reversed? The World Bank Economic Review, 14(3), 415-443. http://dx.doi.org/10.1093/wber/14.3.415

Feldstein, M., \& Horioka, C. (1980). Domestic Saving and International Capital Flows. Economic Journal, 90(June), 314-329. http://dx.doi.org/10.2307/2231790

Frankel, M. (1962). The Production Function in Allocation and Growth: A Synthesis. American Economic Review, 55, 995-1022.

Gouvernement du Cameroun. (2009). DSCE. Yaoundé.

Granger, C. W. J. (1969). Investigating Causal Relations by Econometric Models and Spectral Methods. Econometrica, 35(3), 424-438. http://dx.doi.org/10.2307/1912791 
Harrod, D. (1948). Growth Model. Econometrica, 14, 137-147.

Jappelli, T., \& Pagano, M. (1994). Saving, Growth and Liquidity Constraints. The Quarterly Journal of Economics, 109(1), 83-109. http://dx.doi.org/10.2307/2118429

Kamgnia, B., \& Touna, M. (2002). Le comportement de d'investissement privé au Cameroun: un resserrement de la contrainte financière? Yaoundé.

Keynes, J. M. (1936). The general theory of employment interest and money. Macllalondo.

Levine, R., \& Renelt, D. (1992). A sensibility analysis of cross-country growth regressions. American Economic Review, 82(4), 942-963.

Romer, P. M. (1986). Increasing returns and long-run growth. Journal of Political Economy, 94, 1002-1037. http://dx.doi.org/10.1086/261420

Say, J. B. (1803). Traité d'économie politique. livre I, chapitre XV.

Smith, A. (1776). Recherches sur la nature et les causes de la richesse des nations. Retrieved from http://www.demlib.org/bibliotheque/fiches/smith.htm

Solow, R. (1956). A contribution to the theory of economic growth. Quarter Journal of, Economic, 70. http://dx.doi.org/10.2307/1884513

Toda, H. Y., \& Yamamoto, T. (1995). Statistical inference in vector auto regressions with possibly integrated process. Journal of Econometrics, 66, 225-250. http://dx.doi.org/10.1016/0304-4076(94)01616-8

Turgot, A. (1766). Réflexion sur la formation et la distribution des richesses. Retrieved from www.herodote.net/Anne_Robert_Turgot_1727_1781_-synthese-1766.php

Wouofo, C. (2006). Le point d'achèvement de l'initiative pays pauvres très endettés: les retombées.

World Bank. (2007). World Development Indicators. CD-ROM.

Yoon, J. (1993). Chain Condition, Ambiguity of Government and Derivational Grammars. NELS, 21.

\section{Note}

Note 1. AIC: Akaike information criterion, 2 SC: Schwarz information criterion; 3 HQ: Hannan-Quinn information criterion.

\section{Appendix A}

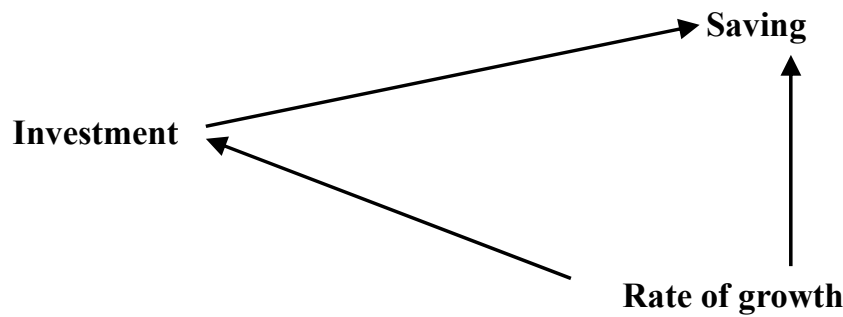

Figure A1. Results of causal test

$\rightarrow$ Direction of causality test.

\section{Copyrights}

Copyright for this article is retained by the author(s), with first publication rights granted to the journal.

This is an open-access article distributed under the terms and conditions of the Creative Commons Attribution license (http://creativecommons.org/licenses/by/3.0/). 